\title{
The eBook Revolution: Policy Issues in a Changing Market
}

\begin{abstract}
The technological advances of our time provide vast opportunities to develop and improve existing services and access to information. However, with new opportunities come new challenges. In 2012, public libraries faced many challenges when the Big Six publishers (Macmillan, Hachette, HarperCollins, Penguin, Random House, and Simon \& Schuster) made abrupt and drastic changes to their policies, restricting libraries' access to the ebooks they publish. This paper explores the positions of the major stakeholders involved in this policy issue: publishers, public libraries, library patrons, authors, and booksellers. The emerging roles of small publishers and self-publishers are discussed, along with effects of the policy changes, current initiatives to resolve the issue, and the future outlook.
\end{abstract}

\begin{abstract}
About the Author(s): Gayle Graham is a second-year student in the Master of Library and Information Studies program at Dalhousie University. Through extensive work experience in both academic and government library settings, Gayle has acquired a strong working knowledge of current issues that impact libraries universally. Gayle believes in ensuring the sustainability of libraries and library practises through fostering the compatibility of services with new and emerging technologies, and possesses a growing interest in policy development. This paper was originally written for Anatoliy Gruzd's Information Policy class (INFO 6610).
\end{abstract}




\section{Introduction}

The growing demand for ebooks is indicative of an exciting new technological revolution. According to a Pew survey, $28 \%$ of American adults reported reading an ebook in 2013, while only 17\% of American adults report having read an ebook in 2010 (Zickuhr \& Rainie, 2014). However, like every major change, the rise of ebook popularity comes with various challenges that must be overcome. The evolution from paper books to ebooks strongly affects publishers, authors, libraries, library patrons, and booksellers. One complex issue is the ongoing debate around the revision of policies accompanying the shift to ebook format. Publishers have started to implement revised policies for the digital age, which affect each aforementioned stakeholder in different ways. This paper will investigate the impacts of these policy changes, as well as each of the major stakeholders' perspectives and arguments.

The need for policy changes regarding ebook distribution has been widely recognized by publishers and the library community in recent years (Albanese, 2012b), and has been the subject of much discussion. This includes talks at conferences (Albanese, 2012a), and meetings between the American Library Association (ALA) and major publishers in an attempt to reach an agreement on a pricing and/or licensing model that would be satisfactory for both parties ("ALA, Publishers," 2012). However, in September of 2012, ALA president Maureen Sullivan wrote and published an open letter to publishers, expressing her frustrations with the publishers' new ebook policies, and their impacts on libraries and their patrons. On the behalf of both parties, she wrote:

Given the obvious value of libraries to publishers, it simply does not add up that any publisher would continue to lock out libraries. It doesn't add up for me, it doesn't add up for ALA's 60,000 members, and it definitely doesn't add up for the millions of people who use our libraries every month (Sullivan, 2012, para. 6).

What would prompt such a strong reaction from the president of ALA? To fully understand Sullivan's frustrations, one must investigate the policy changes in question.

\section{The Policy Changes}

Until very recently, libraries' access to resources in the ebook market was comparable to that of individual consumers. Generally, when purchasing ebooks, libraries paid the retail price (Cushing, 2012) for copies of ebooks which could be loaned indefinitely (Taylor, 2011), a system analogous to the sale and use of paper 
books. The significant difference is that paper books wear out over time and need to be replaced, while ebooks do not. With this in mind, each of the Big Six publishers implemented a new ebook policy and/or purchasing model specifically for libraries. Penguin stopped selling ebooks to libraries altogether, Random House applied a steep price increase to purchases for libraries (approximately triple the original price), a similar price hike was implemented by Hachette (double the original price), and HarperCollins implemented a 26 checkout limit per ebook copy which would require libraries to re-purchase the license afterward (Albanese, 2012b). Simon \& Schuster also ceased to sell ebooks to libraries (Miller, 2013). To gain a thorough understanding of the reasons for the policy revisions, we must first investigate the position of the Big Six publishers.

\section{The Big Six Publishers}

The rise in popularity of ebooks has created a sense of unease within the publishing world. This uneases stems from uncertainties regarding the logistics of lending through an electronic platform, along with the feared loss of revenue. According to former ALA president Molly Raphael, "Some publishers had the impression that libraries lend to whomever visited their respective websites, thus making collections available virtually worldwide without restriction" (as cited in Kelley, $2012 a$, para. 25). This statement is supported by communications from the publishers themselves. At Penguin, a spokesperson stated that the company ceased its sales to libraries because it was concerned about the security of its ebooks, as well as the personal information of the library patrons who borrow them (Maloney, 2012). For the remaining publishers of the Big Six, the motivation for the policy change was largely the fear of losing sales.

Alison Lazarus, president of sales at MacMillan, stated, "We want to insure that customers who have typically been book buyers do not migrate their purchasing into borrowing as accessibility to our books becomes frictionless" (Kelley, 2012a, para. 8). Similarly, Italie (2013a) points to a fear of library ebook loans replacing sales as the reason Simon \& Schuster ceased sales of their ebooks to libraries. Random House was also seeking to adjust its revenues. As a Random House representative explains:

We believe that pricing to libraries must account for the higher value of

this institutional model, which permits e-books to be repeatedly

circulated without limitation. The library e-book and the lending privileges it allows enables many more readers to enjoy that copy than a typical 
consumer copy. Therefore, Random House believes it has greater value, and should be priced accordingly. (Kelley, 2012b, para. 32)

A spokesperson from Hachette shared a similar explanation: "We believe these terms fairly reflect the value to the library customer, that the ebooks will not need periodic replacement as do print copies, and there is no limit on amount of borrowing activity per ebook copy" (Owen, 2012, para. 3).

Most of the Big Six publishers only speak for themselves regarding the ebook issue. However, HarperCollins went further and tried to speak for all the major stakeholders involved. The position of HarperCollins was outlined in an open letter to librarians. In it, Sales Director Josh Marwell (2011) wrote:

We are striving to find the best model for all parties. Guiding our decisions is our goal to make sure that all of our sales channels, in both print and digital formats, remain viable, not just today but in the future. Ensuring broad distribution through booksellers and libraries provides the greatest choice for readers and the greatest opportunity for authors' books to be discovered. (para. 2)

The letter went on to explain that the company's former practise of selling ebooks to libraries without restriction had been initiated at a time when ebooks were in their infancy, and had little impact on the book market overall. Furthermore, Marwell (2011) explains that HarperCollins' newly imposed cap of 26 checkouts, which is sufficient for a year of use for very popular material and longer for less popular items, will serve to maintain balance within the market. As they age, the prices of ebooks will decrease; just as the prices of paperback editions are lower than those of their hardcover predecessors (Marwell, 2011). Furthermore, Marwell argued that the relicensing of ebooks after 26 checkouts is analogous to a paper book wearing out and needing to be replaced (Ojala, 2011). To carry on with the former practise, Marwell (2011) explained, would be disadvantageous to booksellers and authors due to the decreased sales and royalties that would result.

Of the Big Six publishers, HarperCollins seemed to receive the most backlash for their policy change. One possible reason is that HarperCollins was the only publisher to initially cap the number of checkouts allowed per ebook copy. The checkout cap is a new concept which presents unique challenges for libraries' collection management teams, who would need to be aware of the expiration dates of all ebook purchases and relicense them as they expire. Problematically, the Marwell's open letter to 
libraries makes claims about the market which are not supported by the evidence. Such claims will be revisited and refuted throughout this paper.

\section{Libraries}

Publishers' arguments for sustainability and serving all parties' best interests have not convinced librarians. Despite their best efforts at collaborating with publishers to develop an effective new model for ebook sales, many librarians have expressed that they feel powerless on the issue, and furthermore under attack. As Debbie Lebel (2012) of Halifax Public Libraries puts it, "The relationship between publishers and libraries used to be so positive, but somewhere along the way, we (libraries) became the bad guys" (slide 25). In an article titled "Why Do Publishers Hate Us?" Joseph Janes (2013) conveys similar sentiments, questioning how publishers "...turned so quickly and comprehensively against us [libraries]" (p. 31). The conclusion at which Janes arrives is their great fear of change (2013). Librarian Brian Kenney states, "... it's pretty clear that many publishers just don't care" (Albanese, Milliot, \& Reid, 2013). Many furious librarians, in addition to writing letters to the publishers involved, have taken to social media to express their outrage. On Twitter, librarians' comments on the subject include, "It takes a lot of hubris to kick libraries when they're down. You stay klassy [sic] HarperCollins," and "Imagine if our physical books had to be burned after a year of use. To me, it's chilling, dystopian" (Boog, 2011 , para. 4). The Pioneer Library system in Oklahoma posted a video on YouTube showcasing the physical condition of several high-circulation print books. The position they take on the issue is that a benchmark of 26 checkouts is an unrealistic limit in comparison to the life of a hard copy book (Ojala, 2011). The video concludes with an invitation for viewers to contact HarperCollins and express their opinions on the company's new policy (normanlibrary, 2011).

Overall, librarians are angry about the policy changes. As ebook prices soar, library budgets are static or even shrinking, and therefore cannot meet the demands of publishers' pricing schemes. One public librarian reports that ordinarily, for every two patrons on a waiting list, her library will purchase another copy of the book in demand. However, due to the high cost of ebooks, her library was forced to reduce the number of purchases to one ebook for every five patrons on the waiting list (Kelley, 2013). Fewer available copies results in significantly longer wait times and reduced access for library patrons. When ebook sales to libraries are restricted entirely, libraries completely lose the ability to provide their patrons with access to those resources. Since a fundamental library mission is to provide access to information, libraries cannot fulfill their role when new acquisitions become either unaffordable or impossible to 
obtain. As a result, the decrease in available resources will ultimately affect the citizens who rely on public libraries for their information needs.

\section{Library Patrons}

Frustrated with their lack of power in resolving the issue, many librarians in the United States have actively turned to the public to make their voices heard on the issue (Miller, 2013). In her open letter to publishers, ALA president Maureen Sullivan (2012) encouraged public involvement by asking readers, "So, which side will you be on?" (para. 10). The quest for public support makes sense, as libraries exist to serve readers, and it is ultimately the reading public who will be most affected by the ebook policy changes.

Indeed, it did not take long for library users to begin to notice the impacts of the policy change. A recent poll indicated that $53 \%$ of Americans aged 16 and up think that libraries should definitely offer a wider selection of ebooks (Zickuhr, Rainie, \& Purcell, 2013). That being said, many titles and authors cannot be accessed by patrons in ebook format because the libraries simply cannot afford to buy or license them under the new policies (Miller, 2013). To further complicate matters, any titles purchased from HarperCollins automatically go into lockdown mode as soon as they reach the aforementioned limit of 26 checkouts. This restriction makes the accessibility of the libraries' ebooks highly unpredictable and frustrating for patrons, who face the added challenge of navigating different plug-ins and systems for different publishers with different policies (Albanese, et al., 2013). This added confusion increases the number of patrons who already visit the library for assistance in learning how to use their e-readers. One librarian states that, as a result of the inconsistencies, "We're devoting bigger and bigger chunks of our most serious resources, our staff, to helping people enter a market in which we are barely allowed to participate. And you wonder why we're so ticked off?" (Albanese et al., 2013, p. 22).

\section{Authors}

Of course, authors are among the most prominent stakeholders in the issue of ebook policies. One argument put forth by HarperCollins as a justification for their policy change was to protect the authors. This is because they would be negatively impacted by decreases in sales and royalties (Marwell, 2011). However, the evidence so far suggests that this concern is largely unfounded. Evidently, the main reason for authors' continued prosperity is their willingness to adapt to the changing environment by experimenting with self-publishing through the internet and social media tools, as well as such self-publishing platforms like those provided by Amazon and Apple 
(Herther, 2012). Joe Konrath, a self-publishing author, notes, "I'm selling 3000 ebooks a day by pricing reasonably. There aren't too many Big 6 authors selling that well. And I'm getting much better royalties than they are" (Herther, 2012, "Where Stand the Authors?" section). The self-publishing revolution exploded in 2012 (Albanese et al., 2013) and the potential for its continued success looks promising. The shift in user preference to ebook format, along with the power of the internet, has made it possible for authors to thrive by launching their own books independently. It is no longer essential for established publishers to serve as intermediaries between authors and consumers to ensure that books reach their audiences. Furthermore, selfpublishing authors have a unique advantage over large established publishing companies. Specifically, they can "...outsell, outcompete, outdistribute, and outmarket" (Albanese et al., 2013, p. 22) the Big Six publishers by making their books available more quickly, conveniently, and cheaply than large publishers can.

When authors speak out on the issue, they are by and large supportive of libraries. Author Chris Dolley highlights the importance of libraries in broadening readership by facilitating the discovery of authors' works by potential readers (Enis \& Schwartz, 2012a). In the comments section of Maureen Sullivan's open letter to publishers, one anonymous author sympathetically asks what authors can do to help ("Can authors help?" 2012). Recently, ALA has initiated an official partnership between libraries and authors. By signing on to the Authors for Library eBooks campaign, a number of authors are showing their support for libraries and raising awareness of the issue (State Library of Western Australia, 2013). Some authors have even begun to sell their ebooks directly to libraries, eliminating publishers and their policies from the transactions entirely (Knight, 2012). Libraries, readers, and authors are largely united on the issue. Stakeholders who are less involved but equally affected are the booksellers.

\section{Booksellers}

HarperCollins identified booksellers as one of the stakeholder groups that would suffer adverse effects if not for their policy change (Marwell, 201 1). In reality, independent bookstores were identified as an important outlet for book discovery and sales in 2012 (Albanese et al., 2013). It is predicted that bookstores' future relevance will be determined by their willingness to adapt to consumer preferences, including being flexible in the variety of formats they make available to customers (Albanese et al., 2013). Importantly, studies have shown that people who borrow books from libraries also buy books (Miller, 2013), indicating that borrowing and buying are not at opposite ends of the spectrum, as HarperCollins suggests (Marwell, 2011). The relationship 
between borrowing and buying is more complex and the two actions are largely complimentary as opposed to conflicting. A survey published in Library Journal revealed that over $50 \%$ of library patrons purchased books written by authors they had discovered at a library (Kelley, 2012a). Therefore, a well-stocked and well-used library benefits booksellers whose sales can be boosted by the discovery of resources within libraries.

HarperCollins' argument to protect book sales (Marwell, 2011) is paradoxically paired with the mandate to make purchasing more difficult for libraries. By restricting libraries' purchasing power, HarperCollins is drastically cutting the very sales that the company seeks to protect. In the process, HarperCollins is losing the sales from libraries, as well as subsequent sales that would have followed from potential customers' discovery of ebook titles in libraries. Since library patrons would make their purchases at bookstores, a decrease in their discovery of new titles within libraries would decrease their number of book purchases. The booksellers who make these sales would lose profits as a result.

\section{Why the Policy Change does not Work}

So, what can we learn from the current issue of ebook licensing and pricing? A common theme on all sides of the issue is the need for adaptability. It is neither sustainable nor beneficial for any stakeholder to continue thinking in terms of the old business model, in which publishers control the distribution and sales of paper books that wear out and need replacement. With this in mind, it seems impossible that publishers will be able to continue enforcing their new policies as they are. Indeed, there are already examples emerging to support this statement, which will be discussed throughout this section.

Simon \& Schuster, one of the publishers that had ceased ebook sales to libraries entirely, violated its own policy when one of its publications, titled The Year We Left Home, was selected for the All lowa Reads program. After the book was appointed for this honour, the selection committee was very disappointed to learn that their choice was not available to libraries in ebook format, a selection criterion that ensures broad accessibility. Simon \& Schuster responded to pressures from the selection committee by making the title available for libraries to purchase in ebook format ("Simon \& Schuster," 2012). About the incident, a marketing director from Simon \& Schuster states, "This is not our policy as a general rule, but l've spoken to my colleagues about the impact of The Year We Left Home being chosen for All lowa Reads and how that is an important component" ("Simon \& Schuster," 2012, para. 6). Another spokesperson 
stated, "We can be flexible where circumstances merit," ("Simon \& Schuster," 2012, para. 3). Because Simon \& Schuster made a value judgement in this situation regarding which circumstances warrant the sale of ebooks to libraries, the publisher is essentially deciding which books the public can and cannot access instead of allowing them to choose their reading material for themselves. The publishers' role is to provide content, not to censor it according to their own mandates. In addition, a policy that requires exceptions through constant evaluations of individual situations does not serve its purpose. It is difficult to enforce, difficult to follow, and not feasible in the long-term.

MacMillan and Penguin launched pilot projects which, though still restrictive, have restored some ebook access to libraries (Enis, 2012). Such initiatives are wise, as one of the initial reactions among libraries was the consideration of boycotting HarperCollins (Ojala, 2011), a sentiment which could theoretically apply to every publisher who implements an unpopular policy. Although many libraries would be reluctant to act on this impulse and sacrifice all electronic access to the works of popular authors that these prominent publishers provide, some are doing just that. Douglas County Libraries of Colorado are leading a revolution in the boycott of all publishers with restrictive policies in favor of smaller ebook publishers with more favorable terms (LaRue, 2012). An open letter from Douglas County Libraries reports that the library system purchases from 12 publishing groups who offer discounts on ebooks, which libraries can purchase and own outright (LaRue, 2012). Furthermore, it has been reported that library e-lending practises account for as much as $40 \%$ of small publishers' business in Canada ("Folding shelves," 2013). In the event that the boycotting of the Big Six continues and spreads, the major publishers are at risk of being pushed out of the ebook industry altogether as small publishers gain popularity among the library community.

Another threat to the Big Six publishers is that, in the words of Debbie LeBel (2012), "Random House has drastically increased prices to libraries, under the guise of maintaining a relationship with us, while seemingly turning a blind eye to the pirating of ebooks" (slide 25). Similarly, one online commenter points out that in the absence of ebook availability from libraries, readers will go on sharing ebooks with one another through various online platforms. Even in the event that libraries are removed from the equation, ebook lending will continue (Godelnik, 2011). One role that libraries play is to actively enforce and promote copyright law, for the sake of preventing illegal content sharing. If libraries cease to participate in the ebook market, the education they provide to the public with regard to their fair use may diminish. As a result, illegal sharing of ebooks is likely to rise, and publishers' sales are likely to decline. 


\section{Toward a Solution}

Despite strong opposition to the change, there is a sector of the library community that recognizes the potential of the publishers' new policies. The supporters assert that the new policies could evolve to satisfy both the publishers and librarians, but compromises and revisions are required. Michael Kelley (2012c), for one, suggests that the circulation cap imposed by HarperCollins could be raised to accommodate more than 26 checkouts. Alternately, HarperCollins could implement a time limit, but he argues that such a limit should be higher than the estimated year of access. A little modification could potentially go a long way. Many opportunities exist for publishers in the ebook market who are willing to venture out of their comfort zones to try out new practises and new roles. For example, new software was developed in 2012 that would allow publishers more control over the library lending side of the profession, enabling them to set due dates and expiration terms and thereby be more directly involved with library patrons' transactions (Enis \& Schwartz, 2012b). Rather than compete with self-publishers, there is potential for major publishers to collaborate with self-publishers to develop a new business model. It has been suggested that many authors are not interested in the business side of publishing, and may welcome opportunities to sign contracts with established publishers who can provide the services of marketing and production after their self-published work gains popularity and success online (Herther, 2012). Perhaps publishers' fears of the changing ebook market could be minimized by looking forward and forming new partnerships with self-publishing authors who could provide new sources of revenue. In that case, publishers' ebook sales, though still important, would become less crucial to the survival of the companies.

\section{Current State of Affairs and Initiatives}

In the United States, the state of ebook availability to public library patrons has become such a concern that governments have begun to step in. In Connecticut, the governor has signed legislation launching ebook public library study, mandating an investigation of ebook availability to public library patrons and calling for recommendations to increase the level of availability (Price, 2013). In Maryland, the government is taking similar action: "to examine this issue and seek any appropriate remedy so that county library users will have the access to materials in a reasonable and non-discriminatory manner" (as cited in Hoffelder, 2013). Government involvement in the issue demonstrates that it is serious enough to cause significant social problems if left unattended. Should the restriction of ebooks to libraries continue over time, we might be faced with a deepening divide between those individuals who can afford to buy their own ebooks, and those who cannot. One blogger laments, 
"...it's... clear that letting the free market sort itself out simply isn't working" (Hoffelder, 2013). Such a statement is understandable, but perhaps premature. Although the journey has thus far been rough and uncertain, there has been progress.

As of April 2, 2013, libraries are now able to buy and lend Penguin's ebook titles on the same day the hardcover editions are released, at prices that are comparable to the print versions (Enis, 2013). Although Penguin continues to apply restrictions to libraries, significant progress has been made since the company's mandate to cease sales to libraries altogether in 2012 (Albanese, 2012b). As of September 25, 2013, libraries can purchase Penguin titles through OverDrive on a one-year licensing agreement. So far, Penguin's ebooks are only available to libraries in the United States, but the scope is expected to expand in the near future (Chant, Enis, \& Schwartz, 2013). Hachette, Simon \& Schuster, and Macmillan are similarly softening their restrictions by increasing the number of ebooks available to libraries, and offering pilot programs respectively (Italie, 2013b).

Christina de Castell (2013) of Vancouver Public Library strongly advocates the importance of continuing to strive towards a solution which would satisfy both the publishers and the library community. In Canada, a number of initiatives intended to resolve the ebook dilemma are currently underway. Representatives from the Canadian Urban Libraries Council (CULC) have begun to speak at publishers' conferences to spread awareness of the libraries' roles and programs, and thereby restore trust in the partnership. ReadersFirst focuses on the technological anomalies faced by library patrons. The principles outlined by ReadersFirst assert that patrons should be able to perform comprehensive searches and manage library accounts from a single interface, and to access a wide variety of ebooks from several distributors on the device of their choice (de Castell, 2013). eBOUND Canada focuses simultaneously on the issues of technology and content availability. One of the goals for lending practises of ebooks includes a 40 checkout cap per purchased title, which would be more sustainable than HarperCollins' limit of 26 checkouts. Additionally, eBOUND suggests that small libraries in particular would benefit from bundled ebook titles, comparable to a cable television package (de Castell, 2013). Across North America, compromises are emerging and the issue is approaching a resolution.

\section{Future Outlook}

So, what does the future hold? Opinions abound, predicting every extreme. "If publishers cease to exist," asks Christina de Castell (2013), "where will libraries be in five years?" 
(conference presentation, June 1). Meanwhile, others imagine a bright future of ebook prosperity without publishers. According to James LaRue, director of Colorado's Douglas County Libraries system, "It is time for the library to step up as the nurturer of content creation" (Wright, 2013). LaRue envisions a future in which libraries, and even the public, will fulfill a publishing role (Wright, 2013). Currently, the future is very uncertain. However, there is widespread agreement that the library/publisher relationship has shifted, and will continue to change over time.

\section{Conclusion}

The evolution of technology has made profound impacts on the information field. Even the definition of what we consider to be a "book" has changed significantly. Only a short time ago, "book" referred exclusively to a physical entity made of paper and ink. Now, the definition of "book" also includes an electronic file, accessible from any location on a personal device. To adapt, the role of libraries has been changing from a place to store a physical collection of books, to one that serves as an access portal to electronic resources. Booksellers have broadened their horizons to make alternate formats available, and authors have been experimenting with selfpublishing electronically. It is reasonable, and necessary, for publishers' roles and policies to similarly adapt in order to fit the current market and remain viable in a future that is uncertain, but undoubtedly electronic. However, it is always crucial to make such changes with accessibility in mind. If the information provided by publishers is not accessible, none of the stakeholders in the ebook policy issue can reach their goals.

Perhaps the future will hold a quicker and more seamless process of content creation, distribution, and sales, one, in which publishers, libraries, and authors work more closely together to achieve their common goal. The details of the arrangement would be refined over time through trial and error. Roles may change, partnerships may emerge, and accessibility should be enhanced. In a world where everything is changing, anything is possible. 


\section{References}

ALA, publishers talk ebooks (2012). American Libraries, 43(11/12), 10.

Albanese, A. (2012a). A sense of urgency? Publishers Weekly, 259(13), 8.

Albanese, A. (2012b). Going public. Publishers Weekly, 259(39), 4-5.

Albanese, A., Milliot, J., \& Reid, C. (2013). 2012: Beyond disruption. Publishers Weekly, $260(1), 20-24$.

Boog, J. (2011, February 25). HarperCollins library ebook policies generate protests. Retrieved March 29, 2013, from http://www.mediabistro.com/galleycat/harpercollins-library-ebook-policiesprotested-on-twitter_b24203

Can authors help? (2012, October 9). Message posted to http://americanlibrariesmagazine.org/news/ala/open-letter-america-spublishers-ala-president-maureen-sullivan

Chant, I., Enis, M., \& Schwartz, M. (2013, September 25). Penguin ebooks return to OverDrive, go national on Axis 360. Library Journal. Retrieved November 5, 2013, from: http://j.libraryjournal.com/2013/09/publishing/penguin-ebooksreturn-to-overdrive-go-national-on-axis-360/\#

Cushing, T. (2012, September 17). Hachette hits libraries with $220 \%$ price increase on its ebooks. Techdirt. Retrieved February 16, 2014, from http://www.techdirt.com/articles/20120914/12211320384/hachette-hitslibraries-with-220-price-increase-its-ebooks.shtml

de Castell, C. (2013, June 1). Ebooks and public libraries: An update. Presented at Canadian Library Association conference, Winnipeg, MB.

Enis, M. (2012, September). Macmillan confirms ebook pilot for libraries. Retrieved March 29, 2013, from http://www.thedigitalshift.com/2012/09/ebooks/macmillan-confirms-ebookpilot-for-libraries/ 
Enis, M., \& Schwartz, M. (2012a). Book view café authors cut ebook deal. Library Journal, 137(12), 16.

Enis, M., \& Schwartz, M. (2012b). Publishers can now set ebook due dates. Library Journal, 137(12), 16.

Enis, M. (2013). Penguin lifts ebook purchase embargo. Library Journal, 138 (8), 17.

Folding shelves (2013, March 23). The Economist. Retrieved February 16, 2014, from http://www.economist.com/news/international/21573966-e-books-meanplot-twist-public-libraries-and-publishers-folding-shelves

Godelnik, R. (2011). (untitled comment). Message posted to http://www.mediabistro.com/galleycat/harpercollins-library-ebook-policiesprotested-on-twitter_b24203

Herther, N. (2012). The ebook wars. Searcher, 20(4), 20-30.

Hoffelder, N. (2013, July 30). Librarians, govt officials call for fair library ebook prices. The Digital Reader [blog]. Retrieved August 9, 2013, from http://www.thedigital-reader.com/2013/07/30/librarians-govt-officials-call-for-fair-libraryebook-prices/\#.UgWQXMKNTIV

Italie, H. (2013a, April 15). Simon \& Schuster changes policy, puts e-books in libraries. MSN News. Retrieved February 16, 2014, from http://news.msn.com/popculture/simon-and-schuster-changes-policy-puts-e-books-in-libraries

Italie, H. (2013b, May 1). Hachette book group, publisher of Stephenie Meyer, expands library e-book catalogue. Ottawa Citizen. Retrieved August 9, 2013, from http://www.ottawacitizen.com/technology/Hachette+Book+Group+publishe r+Stephenie+Meyer+expands+library+ebook/8319323/story.html

Janes, J. (2013). Why do publishers hate us?. American Libraries, 44(1/2), 31. 
Kelley, M. (2012a, February 8). Simon \& Schuster, Macmillan express concerns about library ebook lending after 'positive' talks with ALA. The Digital Shift. Retrieved February 16, 2014, from

http://www.thedigitalshift.com/2012/02/ebooks/simonschuster-macmillanexpress-concerns-about-library-ebook-lending-after-positive-talks-with-ala/

Kelley, M. (2012b, March 2). Librarians feel sticker shock as price for Random House ebooks rises as much as 300 percent. The Digital Shift. Retrieved February 16, 2014, from http://www.thedigitalshift.com/2012/03/ebooks/librarians-feelsticker-shock-as-price-for-random-house-ebooks-rise-as-much-as-300percent/

Kelley, M. (2012c, October 24). Giving HarperCollins's ebook model some credit and more thought. Retrieved March 29, 2013, from http://lj.libraryjournal.com/2012/10/opinion/editorial/a-modest-ebookproposal-a-big-six-publisher-has-already-provided-a-model-to-build-on/

Kelley, M. (2013, November 8). Check it out with Michael Kelley: e-book optimism and lingering concerns. Publishers Weekly. Retrieved February 16, 2014, from http://www.publishersweekly.com:8080/pw/by-topic/industrynews/libraries/article/59942-check-it-out-with-michael-kelley.html

Knight, Z. (2012, September 7). Libraries go direct to indie authors, rather than deal with big publisher ebook limits. Techdirt. Retrieved February 16, 2014, from http://www.techdirt.com/articles/20120903/19185920260/libraries-go-directto-indie-authors-rather-than-deal-with-big-publisher-ebook-limits.shtml

LaRue, J. (2012). An open letter about ebooks and Douglas County Libraries. Retrieved March 29, 2013, from http://douglascountylibraries.org/content/ebooks-and$\mathrm{DCL}$

LeBel, D. (2012, March 2). All you need is money: Budgets and financial plans [Powerpoint slides]. Retrieved from https://dalhousie.blackboard.com/webapps/portal/frameset.jsp?tab_group =courses\&url=\%2Fwebapps\%2Fblackboard\%2Fexecute\%2Fcontent\%2Ffile\%3F cmd\%3Dview\%26content_id\%3D_312110_1\%26course_id\%3D_3313_1\%26fram esetWrapped\%3Dtrue 
Maloney, J. (2012, June 20). Libraries cut e-book deal with Penguin. The Wall Street Journal. Retrieved February 16, 2014, from http://online.wsj.com/news/articles/SB1000142405270230489870457747917405 1216172

Marwell, J. (2011). Open letter to librarians. Retrieved March 27, 2013, from http://www.harpercollins.com/footer/release.aspx?id=938\&

Miller, B. (2013, February 06). Libraries lobby publishers to change e-book policies. The Patriot-News. Retrieved March 28, 2013, from http://www.pennlive.com/midstate/index.ssf/2013/02/libraries_lobby_publish ers_to.html normanlibrary (2011, March 2). HarperCollins 26+ checkouts. Retrieved March 30, 2012, from http://www.youtube.com/watch? v=Je90XRRrruM

Ojala, M. (2011). Challenging ebook lending policies. Information Today, 28(4), 1-37.

Owen, L. H. (2012, September 14). Hachette to raise ebook prices for libraries by $220 \%$. paidContent. Retrieved February 16, 2014, from http://paidcontent.org/2012/09/14/hachette-to-raise-ebook-prices-forlibraries-by-220/

Price, G. (2013). Connecticut: governor signs ebook-public library availability study legislation into law. Library Journal: Info Docket. Retrieved August 9, 2013, from http://www.infodocket.com/2013/05/30/connecticut-bill-to-studylibrary-access-to-ebooks-passes-state-senate-34-0-next-to-governor/

Simon \& Schuster open to selling ebooks to libraries in certain circumstances (2012, December). Retrieved March 30, 2012, from http://www.digitalbookworld.com/2012/simon-schuster-open-to-sellingebooks-to-libraries-in-certain-circumstances/

State Library of Western Australia (2013, July 5). Authors for library e-books. eBooks in Libraries Advocacy [blog]. Retrieved August 10, 2013, from http://ebookadvocacy.wordpress.com/ 
Sullivan, M. (2012). An open letter to America's publishers. ALA News. Retrieved March 27, 2013, from http://americanlibrariesmagazine.org/news/ala/open-letteramerica-s-publishers-ala-president-maureen-sullivan

Taylor, M. (2011, March 6). Well done, HarperCollins: librarians must change old thinking. TeleRead. Retrieved February 16, 2014, from http://www.teleread.com/library/well-don-harpercollins-librarians-mustchange-old-thinking-by-martin-taylor/

Wright, J (2013, May 22). New American libraries supplement examines future of ebook lending. ALA News. Retrieved August 15, 2013, from http://www.ala.org/news/press-releases/2013/05/new-american-librariessupplement-examines-future-ebook-lending

Zickuhr, K., Rainie, L. \& Purcell, K. (2013). Library services in the digital age. Retrieved March 28, 2013, from http://libraries.pewinternet.org/2013/01/22/libraryservices/

Zickuhr, K. \& Rainie, L. (2014, January 16). E-reading rises as device ownership jumps. Pew Research. Retrieved February 16, 2014, from http://www.pewinternet.org/2014/01/16/e-reading-rises-as-deviceownership-jumps/ 